\title{
Assessing the Effects of Upstream Dam Developments on Sediment Distribution in the Lower Mekong Delta, Vietnam
}

\author{
Trieu Anh Ngoc \\ Faculty of Water Resources Engineering, Thuyloi University, Ho Chi Minh City, Vietnam \\ Email:ngocta@tlu.edu.vn
}

How to cite this paper: Ngoc, T.A. (2017) Assessing the Effects of Upstream Dam Developments on Sediment Distribution in the Lower Mekong Delta, Vietnam. Journal of Water Resource and Protection, 9, 822-840.

https://doi.org/10.4236/jwarp.2017.97055

Received: April 3, 2017

Accepted: June 18, 2017

Published: June 21, 2017

Copyright $\odot 2017$ by author and Scientific Research Publishing Inc. This work is licensed under the Creative Commons Attribution International License (CC BY 4.0).

http://creativecommons.org/licenses/by/4.0/

\begin{abstract}
The Lower Mekong Delta in Vietnam experiences widespread flooding annually. About 17 million people live in the Delta with agriculture as the major economic activity. The suspended sediment load in the Mekong River plays an important role in carrying contaminants and nutrients to the delta and changing the geomorphology of the delta river system. In recent decades, it is generally perceived that the flow and sediment transport in the Mekong River have changed due to climate change and development activities, but observed sediment data are lacking. Moreover, after natural floodplains, the sediment deposition has replaced by dense river systems as resulting in floodplain compartments protected by embankments. This study is aimed to investigate impacts of changing water flow on erosion/deposition in the Lower Mekong Delta. We used Mike 11 hydrodynamic model and sediment transport model for simulating the flow and sediment transport. Various scenarios were simulated based on anticipated upstream discharges. Our findings provide the positive and negative impacts to the changes in sediment transport on agriculture cultivation in the Lower Mekong Delta.
\end{abstract}

\section{Keywords}

Dong Thap Muoi, Sediment Transport, Lower Mekong Delta, Mike Model

\section{Introduction}

The Mekong River with the length of about $4800 \mathrm{~km}$ and drainage area of about 975,000 $\mathrm{km}^{2}$ flows through six countries: China, Myanmar, Thailand, Laos, Cambodia and Vietnam. The Lower Mekong Delta (LMD) with the area of about $39,000 \mathrm{~km}^{2}$ belongs to the Vietnamese territory from the downstream of Phnom Penh. The river splits into two main tributaries, the Tien River and the Hau Riv- 
er. These two main rivers germinate into a dense river network on the flat lowlying and fertile delta of southern Vietnam before draining into the Southeast Sea from Vung Tau to Camau cape, Ngoc et al. [1].

The climate of the Lower Mekong River is tropical monsoon and regulated by two seasons, i.e. wet season from May to October and dry season from November to April. According to data statistic for 85 years from 1924 to 2008, MRC [2], the annual precipitation in the Lower Mekong River is significantly different between the east and west tributaries (1800 - $2500 \mathrm{~mm} / \mathrm{year})$, and the mean annual discharge of the Lower Mekong River is almost $460 \mathrm{~km}^{3}\left(15,000 \mathrm{~m}^{3} / \mathrm{s}\right)$. Around $75 \%$ of the annual discharge occurs in the wet season from July and October, resulting in a large variation in discharge throughout the year with the maximum discharge over $60,000 \mathrm{~m}^{3} / \mathrm{s}$ in the wet season and the minimum of $2000 \mathrm{~m}^{3} / \mathrm{s}$ in the dry season, Letrung et al. [3].

The sediment load of the Mekong River is about $160 \times 106$ tons per year, Milliman and Farnsworth [4], Wild et al. [5], which plays a critical role in carrying contaminants, bacteria, nutrients, pesticides, etc., Cenci et al. [6], Hung et al. [7]. They are also known as fertile sources for agricultural cultivations a sustainable agro-ecosystem in the LMD. However, little is known about the dynamics of the suspended sediment, including spatial and temporal variation of erosion/deposition and transport in the complex channel network of the LMD, Ngoc et al. [1], Hung et al. [8]. A number of recent studies provided some information on sediment deposition and erosion indicated major factors that influence sediment transport in the LMD, Wolanski et al. [9] [10], Tamura et al. [11], Mikhailov and Arakelyants [12], Hung et al. [7] [8] [13], Ngoc et al. [1], Thanh Letrung et al. [3] and Manh et al. [14] [15].

Increasing number of hydropower dams have been built in the Mekong rivers in recent decades. Cascade hydropower dams were constructed in the Langcang basin in China with the total water storage capability of about 40 billion $\mathrm{m}^{3}$. Several studies, Lu and Siew [16], Liu and He [17], and Liu et al. [18], showed that these dams reduced the sediment delivery from the Lancang River to downstream Mekong. Some studies reported that, total suspended sediment (TSS) discharge from the Chiang Saen branch reduced from mean annual 75 million $\mathrm{m}^{3}$ (during the period of 1962-1992) to 35 million $\mathrm{m}^{3}$ (during the period of 1993-2003). Similarly, in the Khong Chaim branch, reduced from 180 million $\mathrm{m}^{3}$ (1962-1992) to 100 million $\mathrm{m}^{3}$ (1993-2003) and in Pakse reduced from 160 million $\mathrm{m}^{3}$ (1962-1992) to 120 million $\mathrm{m}^{3}$ (1993-2003), MRCS/WUP-FIN [19], Letrung T. et al. [3].

A large number of sedimentation studies were conducted and published, Steiger et al. [20], [21], Middelkoop [22], Baborowksi et al. [23], Hung et al. [7] [8] [13], Manh et al. [14] [15], Ngoc et al. [1], Habersack et al. [24], however, these studies focused on other aspects such as reservoir sedimentation, urban retention pond, reservoir influence or suspended sediment mobilization and transport in small mountainous catchments.

Therefore, this study aims to investigate the impacts of changes in water flow 
on sediment transport in the LMD in Vietnam under different dam development scenarios. The Mike 11 hydrodynamic model and sediment transport model are used for simulating the flow and sediment transport. Firstly, the hydrodynamic (HD) model including the rainfall runoff NAM model are applied for simulating the changes of water flow and water level in the complex river network system. Then, the sediment transport (ST) model is used to compute spatial variation of sediment erosion and deposition in the river/channel network of the LMD. The results of this study could be a valuable contribution in understanding of construction and operation of hydropower dams and impacts of changing upstream discharges on sediment movement.

\section{Data Setting and Methods}

\subsection{Study Area}

Within the LMD our study area is located in the Dong Thap Muoi (DTM) (see in Figure 1), which is also called the Plain of Reeds. The DTM has an area of $7081 \mathrm{~km}^{2}$ and is shared between three provinces: Long An, Tien Giang and Dong

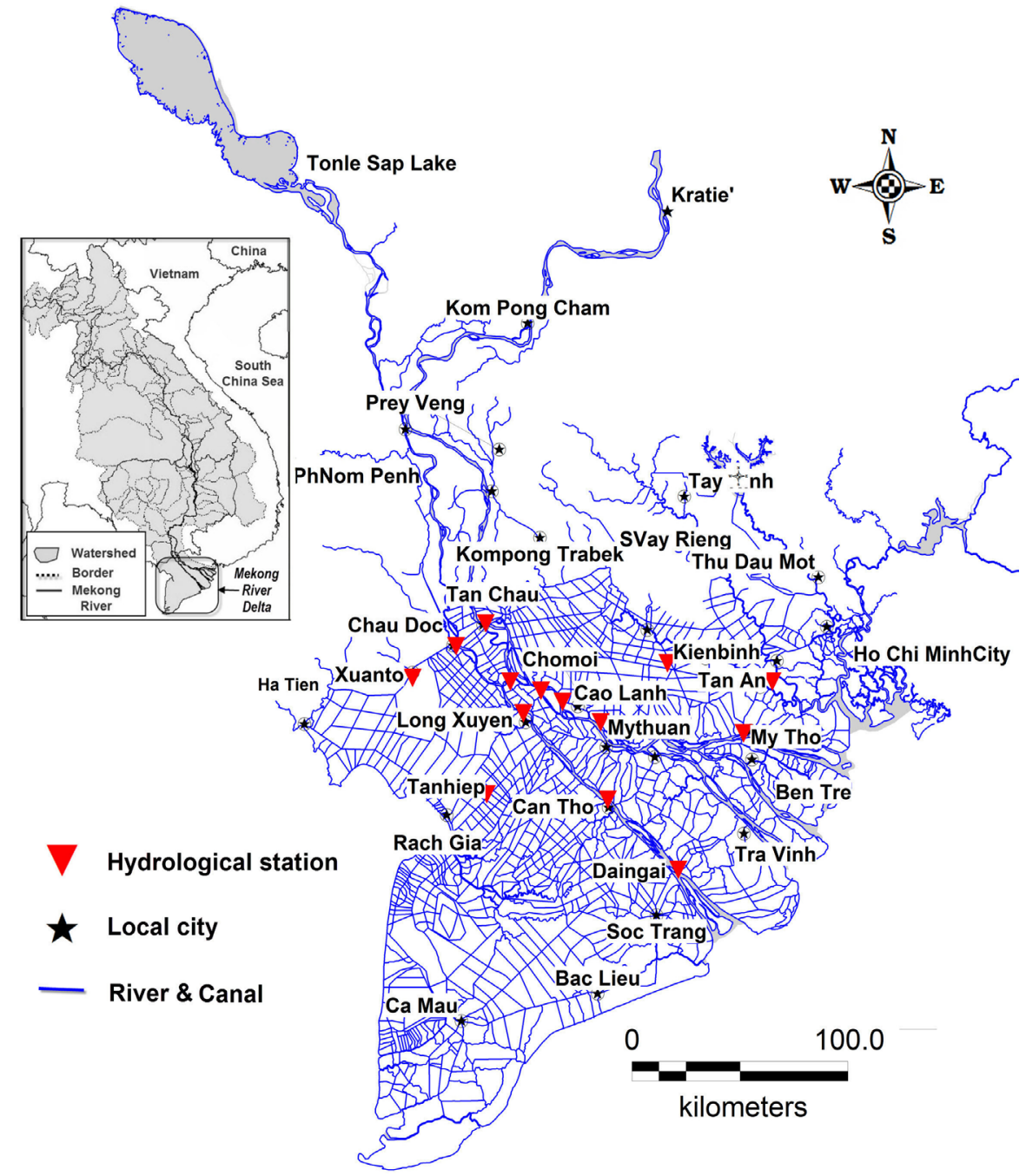

Figure 1. Lower Mekong River and location of hydrological stations. 
Thap. Approximately $70 \%$ of the total area is used for agriculture, while DTM accounts for $36.7 \%$ of the LMD. In its upstream section, the Tien River carries about $80 \%$ of the total discharge of the Mekong River. In addition, a significant flood discharge transfers along Cambodia border into DTM via horizontal canals causing serious flood inundation and affects to agricultural cultivation and human activities. To strengthen the stability and economic development in DTM, the governmental authority has been investing huge budget for improving irrigation and drainage systems in order to control water sources at compartments by low dikes for crops and high dikes for flood protection. The man-made channel and dike systems have greatly altered the natural hydrodynamic conditions in the Vietnamese part of the delta. In combination with the extensive development of dike systems in the last decades, especially after the devastating flood in 2000, the floodplains are increasingly cut off from the natural inundation regime. With characteristics of particular DTM, the channel density of 11.6 $\mathrm{m} / \mathrm{ha}$ is comparable to the average density of the Delta. About $67 \%$ of the dikes in the study area are low dikes, with average crest levels of about $2.5 \mathrm{~m}$, and $33 \%$ are high dikes for flood protection, with average crest levels of about $4.5 \mathrm{~m}$.

\subsection{Data Used}

Hourly discharge and water level data from all the available hydrological stations located in the LMD were used (Table 1) for calibration and validation of Mike 11 hydrodynamic and sediment transport models. The simulation period was chosen from July to December, which covers the entire flooding season (August-October). Rainfall data (daily time series) from 13 stations were used for the NAM hydrological model which was integrated with the Mike 11 model to take into account the runoff generated within the LMD. The Thiessen polygon method was use to obtain sub-catchment rainfallfrom the 13 stations rainfall (Figure 4). At the upstream boundary at Kratie (Figure 1), the suspended sediment data are unavailable. Hence, we derived the sediment discharge boundary condition at Kratie using the relationship between water discharge and suspended sediment concentration (Equation (1) \& Equation (2)).

$$
S S C_{t}^{\text {Kratie }}=10^{\left(-494.02 \log \left(Q_{t}^{\text {Kratie }}\right)\right)^{-4.52}}+2.88
$$

where, $S S C_{t}^{\text {Kratie }}$ is suspended sediment concentration $\left[\mathrm{mg} \cdot \mathrm{L}^{-1}\right]$ at time $\mathrm{t}$ at $\mathrm{Kra}$ tie, $Q_{t}^{\text {Kratie }}$ is water discharge $\left[\mathrm{m}^{3} \cdot \mathrm{s}^{-1}\right]$ at time $t$ at Kratie.

The sediment discharge is calculated by using the following equation:

$$
S S D_{t}^{\text {Kratie }}=2.65 \times 10^{-3} S S C_{t}^{\text {Kratie }} \times Q_{t}^{\text {Kratie }}
$$

where, $S S D_{t}^{\text {Kratie }}$ is sediment discharge $\left[\mathrm{m}^{3} \cdot \mathrm{s}^{-1}\right]$ at time $t$ at Kratie.

The hydrodynamic model was calibrated and validated with the observed discharge and water level data from the year 2000 and 2002. The year 2000 can be considered as a big flooding year and the 2002 as a normal flooding year.. The sediment transport model was calibrated validated using the data of sediment discharge data from 2002. These data were collected from Thuyloi University, 


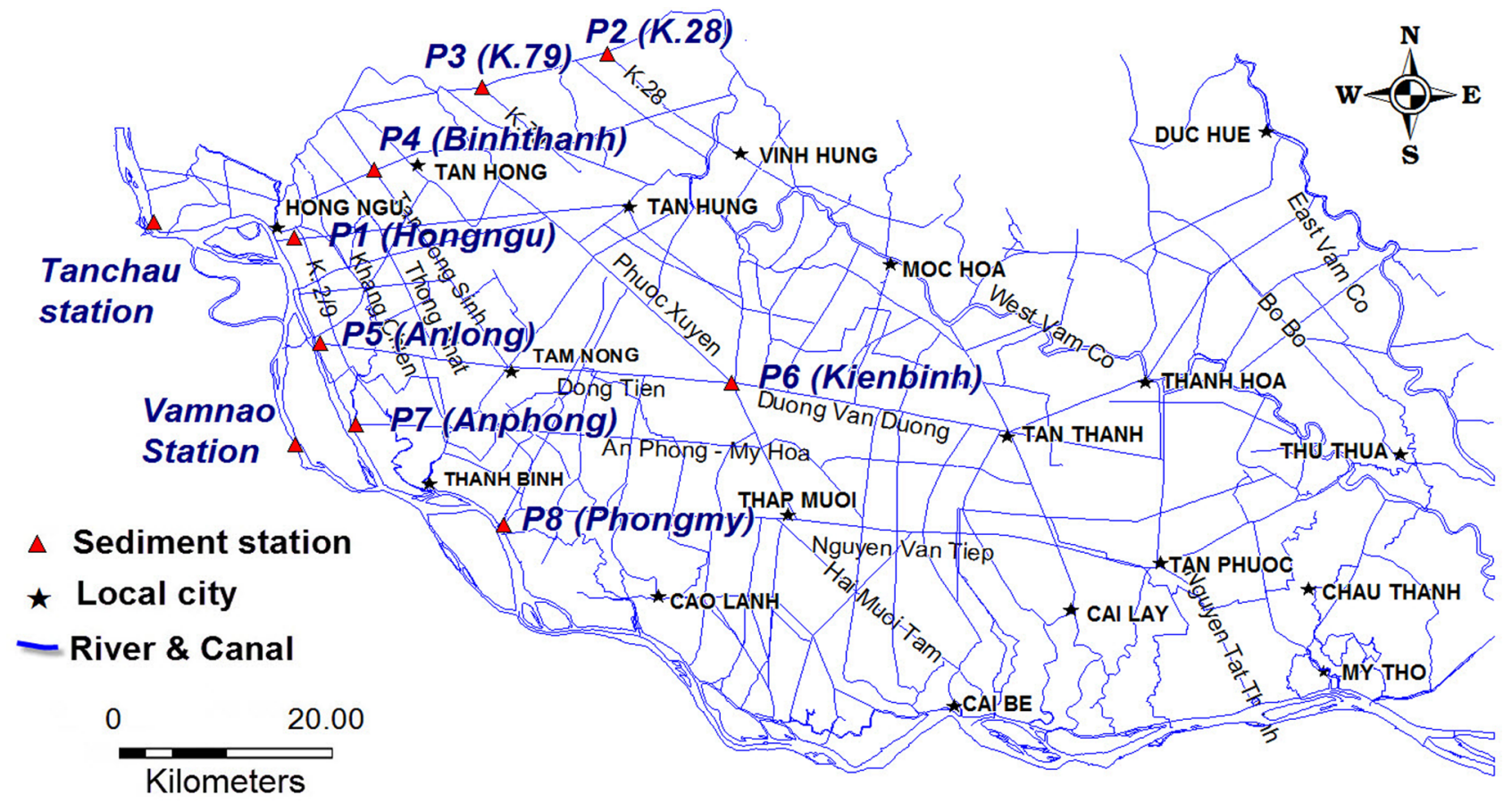

Figure 2. Study area and location of sediment mobile stations.

Vietnam (former Water Resources University). The locations of the data stations are shown in the Figure 1 and Figure 2.

\subsection{Mike 11 Model}

Mike 11 model, developed by DHI, is a modeling system for simulating water flow, water quality and sediment transport in estuaries, rivers, irrigation channels and other water bodies, DHI [25] [26]. It comprises of a number of modules, such as Hydrodynamic (HD), Rainfall Runoff (RR), Advection Dispersion (AD), Water Quality (ECOLab), Sediment Transport (ST) etc. We used the HD module with its fully hydrodynamic method based on Saint-Venant equations for the river flow. The RR and ST modules will be discussed separately below. The MLD is a very complicated network of rivers and channels. All rivers and channels in the LMD and Dongnai-Saigon river system are represented in the model with 4110 branches and reaches with a total length of $24,200 \mathrm{~km}$ and 39,780 cross sections. Three types of river structures are represented, which are 19 free overflow weirs (broad-crested), 14 culverts (rectangular section) and 2429 underflow control structures (see in Figure 3). The control structures are treated as automatic with upstream/downstream water level control. To prevent the flow of sea (saline) water into the paddy fields, the control gates will be closed if the water level in the rivers due to tidal effects is higher than the upstream water level in the paddy fields.

The model consists of 22 upstream inflow boundaries (discharge time series), 58 downstream water level boundaries and 22 sediment inflow upstream boundaries, and rainfall-runoff links to 1682 sub-basins. The upstream model domain was extended up to Kratie (downstream of the Cambodia border) and Tonlesap 


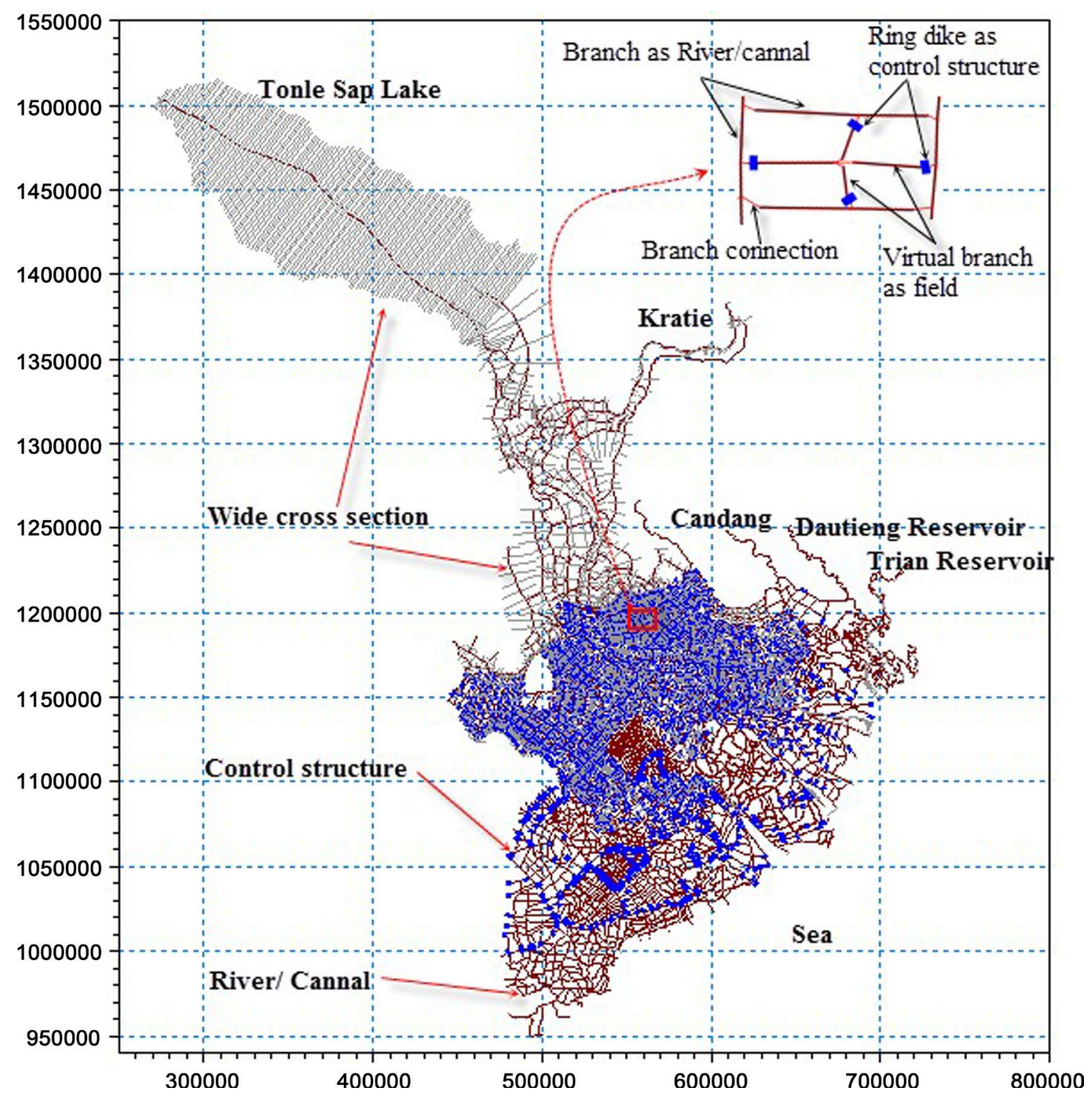

Figure 3. Modeled river network in Mike 11.

Lake. The Manning's roughness values were set by calibration. In most river sections a value of 0.028 was use and in channel reaches the values varied from 0.025 to 0.1 .

\subsection{Mike 11 NAM Model}

The NAM isa conceptual RR model, Havnø et al. [27], Nielsen et al. [28]. It can be integrated with the Mike $11 \mathrm{HD}$ model for computing discharge time series input to the HD model that is generated within the model domain. The model domain can be divided into a number of units or subbasins. NAM treats each subbasin as a lumped unit with 10 main parameters that need to be calibrated. There are 1682 subbasins in our model (Figure 4). For the calibration purpose they were grouped into two types: those in the delta area and those in the upstream of the deltas. The parameters we used are established in earlier studies by Ngoc et al. [29] [30]. 


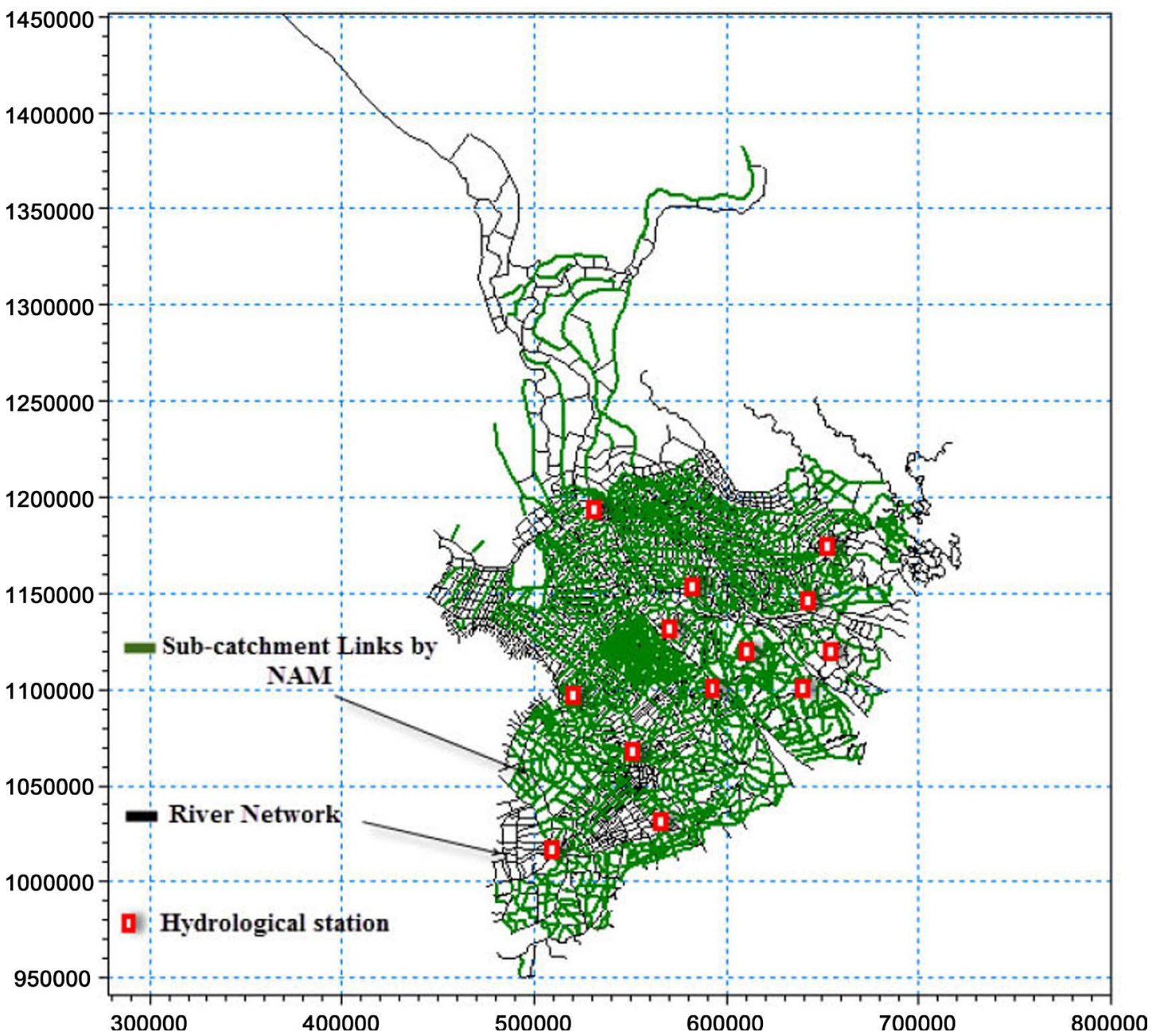

Figure 4. Sub-catchments links in Mike 11 NAM model.

\subsection{Mike 11 ST Model}

The ST model used in Mike 11 is based on Van Rijn model in which the sediment load is divided into bed load and suspended load according to the relative magnitudes of bed shear velocity and particle fall velocity, Van Rijn [31]. When the bed shear velocity exceeds the fall veloctiy, sediment is transported as both suspended sediment and bed load. The sediment properties specified in the model are presented Table 1, which are based on a number of previous studies, Hung et al. [8], Manh et al. [15], Ngoc et al. [1].

Most suspended sediment in the LMD is fine-grained, Hung et al. [7]. MRC/DMS [2] pointed out a $d_{50}=3-8 \mu \mathrm{m}$ in the Tonle Sap River. Sediment analysis from 11 trap sites over large area of the LMD found that grain size of deposited sediment are uniformly distributed with a dispersed grain size distribution of $41 \%$ clay (grain size $<2 \mu \mathrm{m}$ ) and $51 \%$ silt (grain size $2-63 \mu \mathrm{m}$ ), Manh et al. [14]. Hung et al. [7], reported that the average flock size determined for floodplains of the DTM is $\mathrm{d}_{50}=35 \mu \mathrm{m}$, which dominates the sediment depositionover 12 trap sites measured on floodplain of the DTM. They also indicated that range of dispersed and flocculated grain sizes is $d_{50}=2.5-80 \mu \mathrm{m}$, which 
Table 1. Sediment transport parameter set.

\begin{tabular}{cccc}
\hline No. & Item & Value & Description \\
\hline 1 & Relative density & 2.65 & Specific gravity \\
2 & Kinematic viscosity & 1.5 & $\times 10^{-6} \mathrm{~m}^{2} / \mathrm{s}$ \\
$\mathbf{3}$ & Global grain diameter & 35 & $\mu \mathrm{m}$ \\
4 & Grain diameter in border of Cambodia & $10-35$ & $\mu \mathrm{m}$ \\
$\mathbf{5}$ & Grain diameter in Tien River & $40-65$ & $\mu \mathrm{m}$ \\
$\mathbf{6}$ & Grain diameter in DTM & $10-40$ & $\mu \mathrm{m}$ \\
\hline
\end{tabular}

Table 2. Upstream development in irrigation and hydropower dams.

\begin{tabular}{|c|c|c|c|c|c|}
\hline \multirow{2}{*}{ Anticipted Scenarios } & \multirow{2}{*}{ Description } & \multirow{2}{*}{$\begin{array}{c}\text { Total water } \\
\text { demand } \\
\left(10^{6} \mathrm{~m}^{3}\right)\end{array}$} & \multirow{2}{*}{$\begin{array}{c}\text { Irrigated } \\
\text { area } \\
(1000 \mathrm{ha})\end{array}$} & \multicolumn{2}{|c|}{$\begin{array}{c}\text { Total reservoir } \\
\text { capability }\left(10^{6} \mathrm{~m}^{3}\right)\end{array}$} \\
\hline & & & & Lower Mekong & China \\
\hline Baseline in 2002 & $\mathrm{BL}$ & 1620 & 7422 & 6185 & - \\
\hline Low dam development & LDD & 3109 & 8316 & 12,443 & 10,300 \\
\hline Xayaburi dam development & $\mathrm{XDD}$ & 3109 & 8316 & 13,743 & 10,300 \\
\hline High dam development & HDD & 4194 & 11,349 & 26,778 & 22,700 \\
\hline
\end{tabular}

were extensively usedto evaluate a calibration range of $\mathrm{W}_{0}=1 \times 10^{-5}-7 \times 10^{-3}$ $\mathrm{m} \cdot \mathrm{s}^{-1}$, where $\mathrm{W}_{0}$ is the free settling velocity based on the Stoke's law.

\subsection{Proposed Modeling Scenarios}

We base our analysis on a baseline scenario and three future scenarios (Table 2). Year 2002 is considered as the baseline scenario and the future scenarios are based on different levels of dam development in the region. Three levels of dam development are considered, namely low development (LDD), low development plus the Xayaburi dam (XDD) and high development (HDD). The HDD scenario includes all the dams considered in the LDD, the Xayaburi and some additional dams. The reservoir storage capacity of the LDD scenario in the Lower Mekong is almost double of the BL scenario. With addition of the under construction highly controversial Xayaburi, the storage capacity in the lower Mekong will be added by about $10 \%$ of the LDD scenario, but it is not estimated to increase the water demand and irrigation area. The HDD scenario almost doubles the storage capacity in the Lower Mekong as well as in the Upper Mekong in China from that of the XDD scenario.

\section{Results}

\subsection{Model Verification}

To evaluate the performance of Mike 11 model, the coefficients of Nash-Sutcliffe $\left(\mathrm{E}_{2}\right)$, Root Mean Square $\left(\mathrm{R}^{2}\right)$ and Root Mean Square Error (RMSE) were used to express the model's ability to simulate hydrodynamics and sediment transport.

The hydrodynamic model (HD) simulated the period July $1^{\text {st }}$ to December $30^{\text {th }}$ 
Table 3. Coefficients of Nash-sutcliffe, $\mathrm{R}^{2}$ and RMSE between observed and simulated water levels.

\begin{tabular}{lcccc}
\hline No. & Station & Nash-sutcliffe $\left(\mathrm{E}_{2}\right)$ & $\mathbf{R}^{2}$ & RMSE \\
\hline $\mathbf{1}$ & Tanchau & 1.000 & 1.000 & 0.002 \\
$\mathbf{2}$ & Chaudoc & 0.997 & 0.997 & 0.038 \\
$\mathbf{3}$ & Vamnao & 0.975 & 0.984 & 0.088 \\
$\mathbf{4}$ & Longxuyen & 0.933 & 0.937 & 0.112 \\
$\mathbf{5}$ & Chomoi & 0.966 & 0.967 & 0.103 \\
$\mathbf{6}$ & Caolanh & 0.926 & 0.930 & 0.133 \\
$\mathbf{7}$ & Xuanto & 0.978 & 0.985 & 0.130 \\
$\mathbf{8}$ & Kienbinh & 0.911 & 0.927 & 0.224 \\
$\mathbf{9}$ & Tanhiep & 0.940 & 0.970 & 0.144 \\
$\mathbf{1 0}$ & Mythuan & 0.912 & 0.933 & 0.131 \\
$\mathbf{1 1}$ & Mytho & 0.938 & 0.957 & 0.170 \\
$\mathbf{1 2}$ & Cantho & 0.914 & 0.953 & 0.138 \\
$\mathbf{1 3}$ & Daingai & 0.950 & 0.958 & 0.166 \\
$\mathbf{1 4}$ & Tanan & 0.918 & 0.929 & 0.191 \\
\hline
\end{tabular}

2000 with a time step of 10 minutes and output was stored hourly. Observed water levels at 14 hydrological stations during the year 2000 were used for model verification. (locations of data collection sites are shown in Figure 1).

The modelled and observed water level comparison (Table 3 and Figure 5) indicate that the model achieves a greater precision at hydrological stationlocated along the main branches of the Lower Mekong River (Hau and Tien Rivers) than at those located in the secondary canals. This is probably because the complex of river network system, as well as many flood control structures along the main river branches will invariably have a significant effect on the hydrodynamics in the secondary canals. However, the model shows very good agreement with data at most stations with $\mathrm{R}^{2}$ values close to unity Nash-sutcliffe coefficients $\left(E_{2}\right)$ higher than 0.91 . This provides sufficient confidence in the ability of the model to simulate river hydrodynamics.

Next, the model was verified for sediment transport using data obtained in September 2002 using 10 mobile stations (see Figure 2 for locations). The model/data comparisons are shown in Table 4 and Figure 6.

In general, there is good agreement between the modelled and measured sediment fluxes. The error statistics show that model/dta comparisons are very good upstream of the LMD (Tanchau and Vamnao stations) and at the Cambodia border (K28 (P2), K79 (P3), Hongngu (P1), Binhthanh (P4) canals)). In addition, the $R^{2}$ values are much higher than $E_{2}$ values indicating that the model reproduces the trend in observations better than the magnitudes. It should, however, be taken into account that the accuracy of sediment transport measurements is relatively low (compared for e.g. to water level measurements) and 

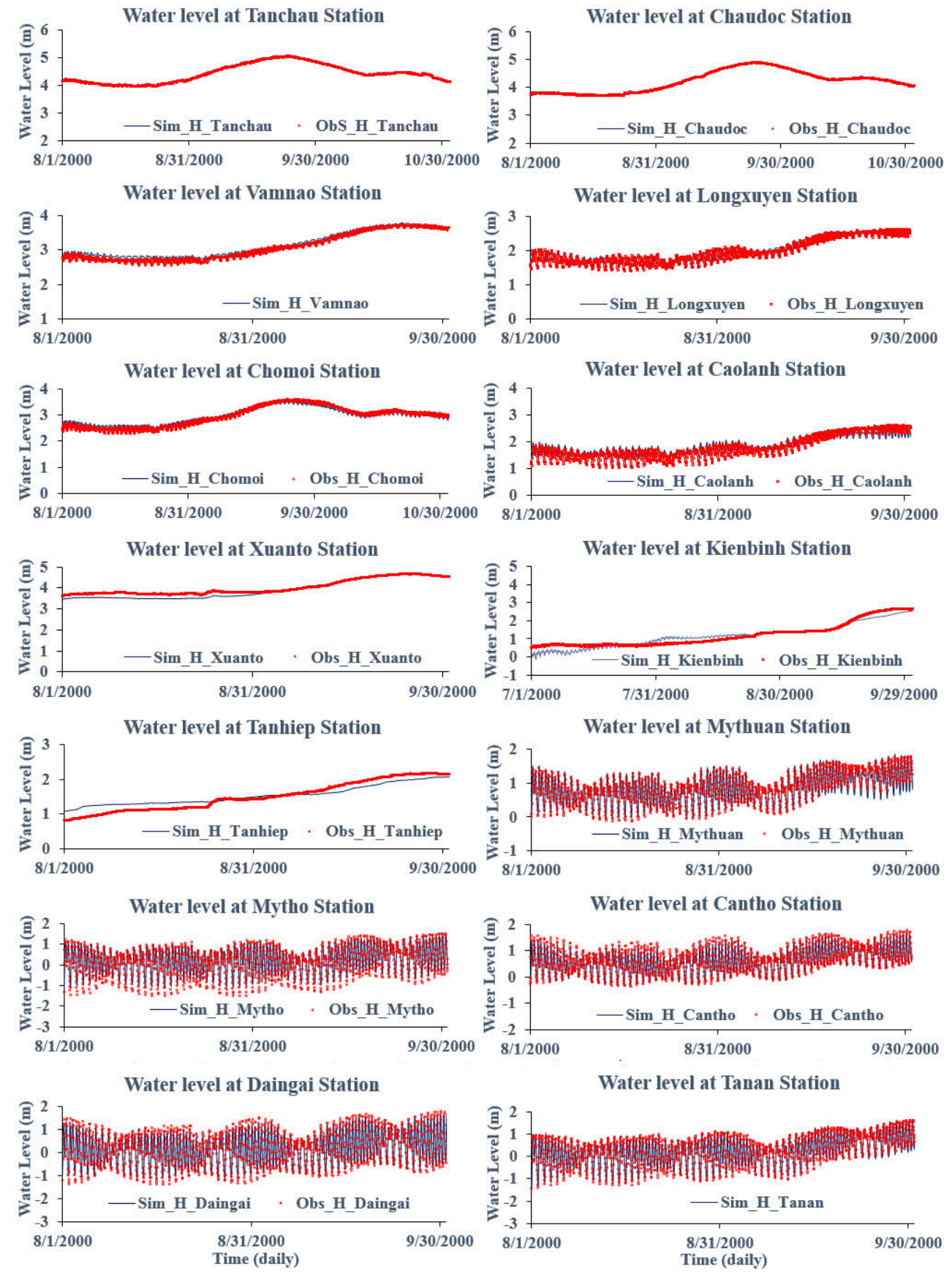

Figure 5. Calibration of observed and simulated water level for 14 stations in 2000.

Table 4. Coefficients of Nash-sutcliffe, $\mathrm{R}^{2}$ and RMSE between observed and modelled daily sediment discharges.

\begin{tabular}{cccccccccccc}
\hline No. & Station & Point & $\left(\mathrm{E}_{2}\right)$ & $\mathbf{R}^{2}$ & RMSE & No. & Station & Point & $\left(\mathrm{E}_{2}\right)$ & $\mathbf{R}^{2}$ & $\mathrm{RMSE}$ \\
\hline $\mathbf{1}$ & Tanchau & & 0.634 & 0.842 & 1.369 & $\mathbf{6}$ & Binhthanh & P4 & 0.703 & 0.898 & 0.011 \\
$\mathbf{2}$ & Vamnao & & 0.575 & 0.734 & 0.541 & $\mathbf{7}$ & Anlong & P5 & 0.561 & 0.904 & 0.040 \\
$\mathbf{3}$ & Hongngu & P1 & 0.604 & 0.928 & 0.050 & $\mathbf{8}$ & Kienbinh & P6 & 0.764 & 0.928 & 0.050 \\
$\mathbf{4}$ & K28 & P2 & 0.595 & 0.741 & 0.010 & $\mathbf{9}$ & Anphong & P7 & 0.392 & 0.735 & 0.005 \\
$\mathbf{5}$ & K79 & P3 & 0.642 & 0.909 & 0.006 & $\mathbf{1 0}$ & Phongmy & P8 & 0.290 & 0.818 & 0.032 \\
\hline
\end{tabular}



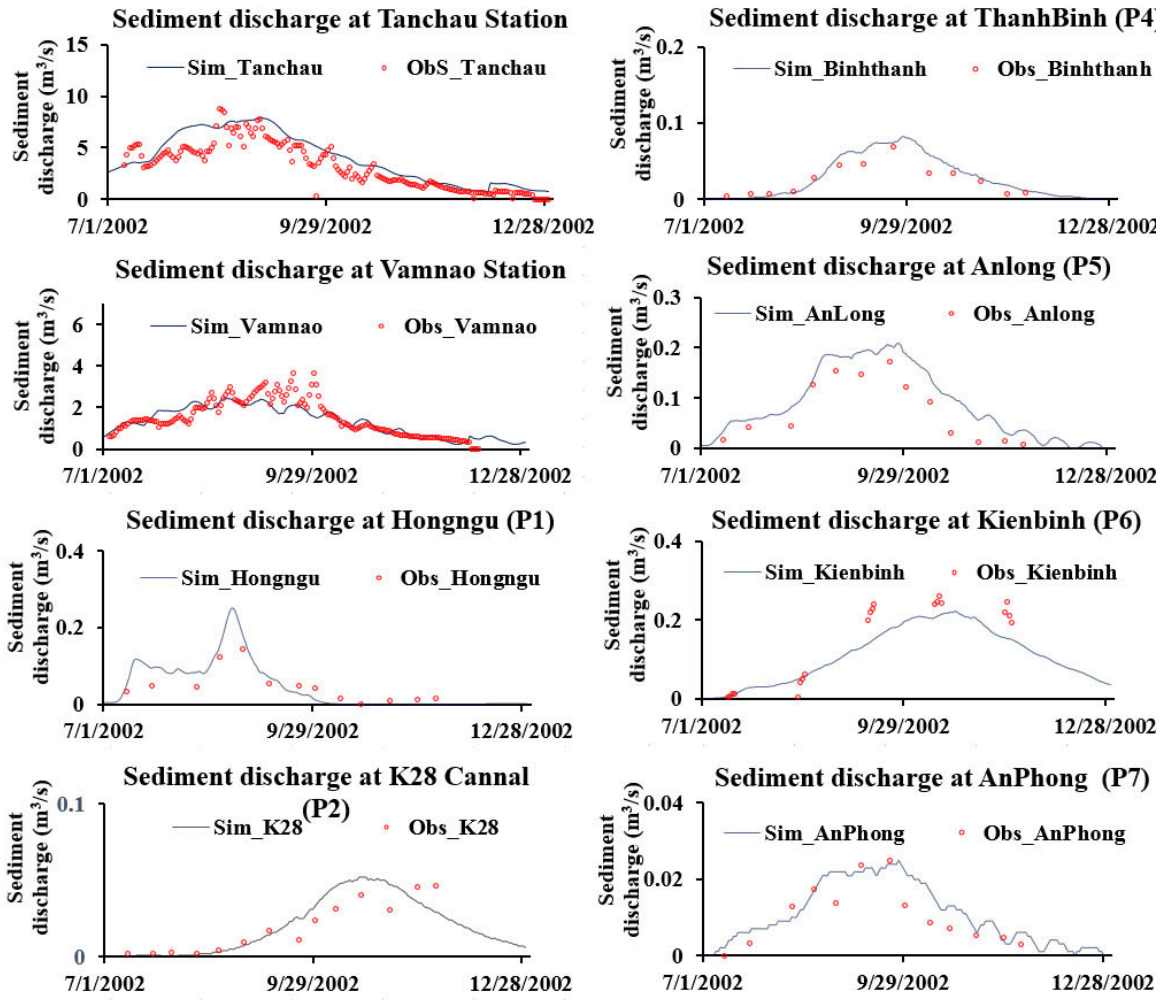

Sediment discharge at K79 Cannal
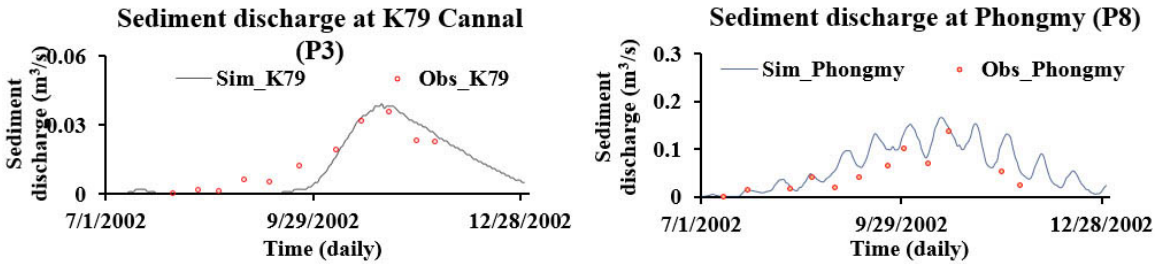

Figure 6. Observed and simulated sediment discharge in 2002.

therefore, the achieved model/data comparisons provide sufficient confidence in the model to proceed with scenario modelling described.

\subsection{Results}

Changes in sediment transport based on upstream dam development scenarios

The increase in water demand for irrigation and water storage in reservoirs will dramatically change the hydrological regime of the main tributaries of the Mekong River, and thus affect the sediment delivery from upstream of the LMD.

Figure 7 shows the flood discharge and sediment discharge at Tanchau station. The sediment discharge for a baseline scenario is higher than all of the development scenarios, confirming that upstream development will result in a significant reduction in sediment delivery to the downstream of the LMD.

Figure 8 shows the total sediment discharge transports via Tien River and Cambodia border to the DTM floodplains affected by upstream development of hydropower dams. The results show that during the 2002 flood season, that sediment would have been brought into the DTM through overbank flow over floodplains at the Cambodia border. As expected, increased water storage in hy- 

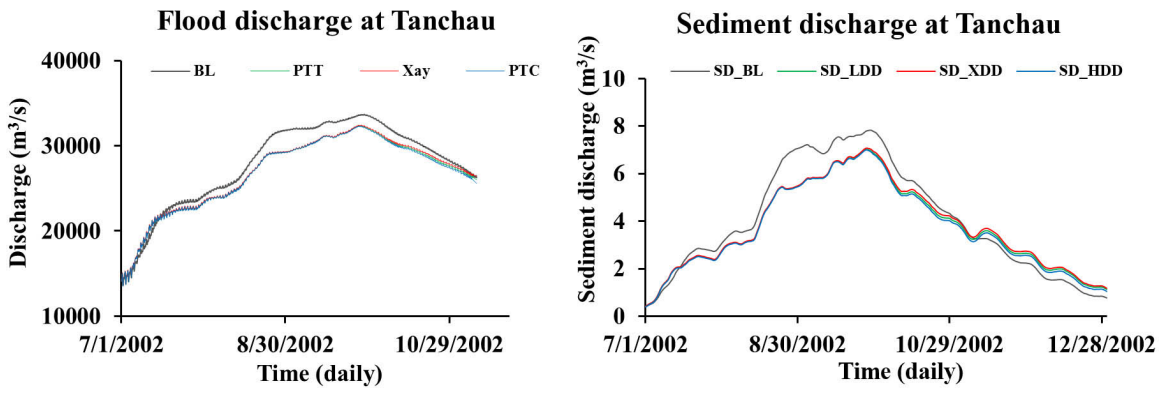

Figure 7. Flood discharge and sediment discharge at Tanchau based on hydropower dam development scenarios.

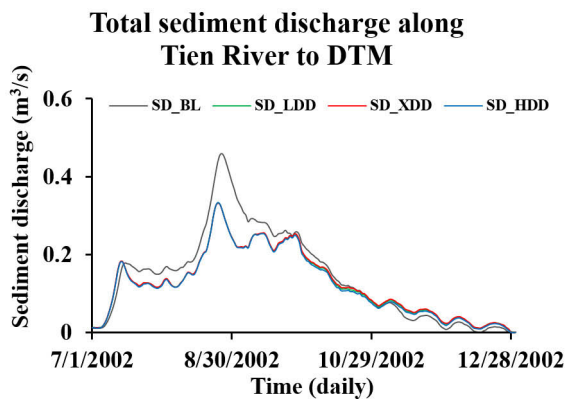

(a)

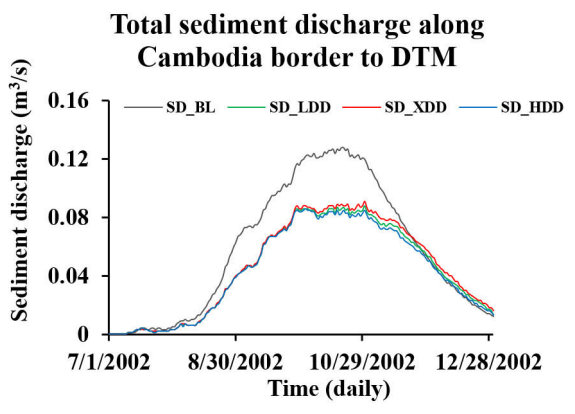

(b)

Figure 8. Total sediment discharge delivery to DTM via Tien River and Cambodia border based on hydropower dam development scenarios: (a) Total sediment discharge delivery to DTM via Tien River; (b) Total sediment discharge delivery to DTM via Cambodia border.

dropower reservoirs (as LDD and HDD) leads to a reduction in the $r$ total sediment transport to the LMD (see Figure 8(b)).

The effect of further developing hydropower reservoirs on sediment transport into the DTM floodplains via Tien River and Cambodia border is illustrated in Figure 9 and Figure 10. Along the Cambodia border, the associated decreases in sediment transport into the DTM floodplains varies from Tanchau to WestVamco River. The sharpest drop (about 50\% of the baseline transport) is at P3 (K79) closer to West-Vamco River (Figure 9). Sediment discharge also decreases by abot $50 \%$ at P2 (K28), and, to a lesser degree, at P4 (Binhthanh) closer to Tanchau station.

Similarly, Figure 10 shows that the sediment supply to the DTM from the Tien River would also be reduced by further development of hydropower reservoirs. In general, therefore, it can be concluded that the further development of reservoirs in the upper Mekong will inevitably reduce sediment delivery to the LMD as well asthe DTM floodplains. However, at the end of flooding season (from November to December), the sediment discharge was slightly increased for all stations. This is an answer for regulation/operation of hydropower dams at the upstream, flooding discharge is partially stored in wet season and released in dry season for electricity generation.

The above results also show that the reduction in sediment supply to the DTM will be practically the same for LDD, HDD and XDD scenarios, with the reduc- 


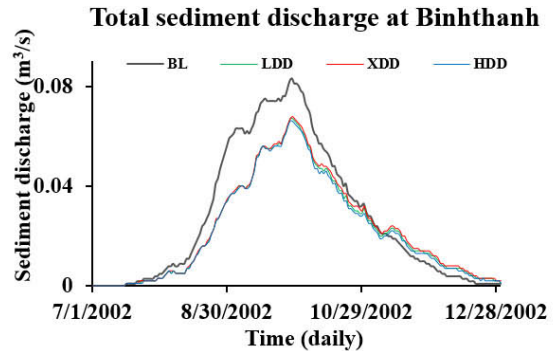

(a)

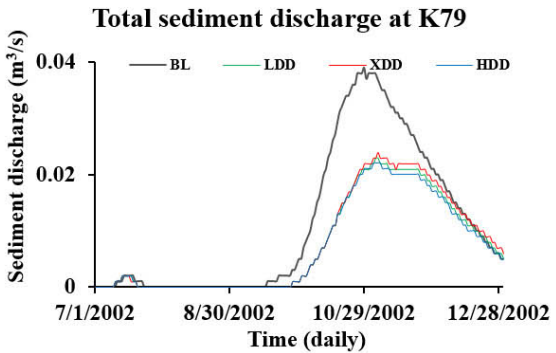

(b)

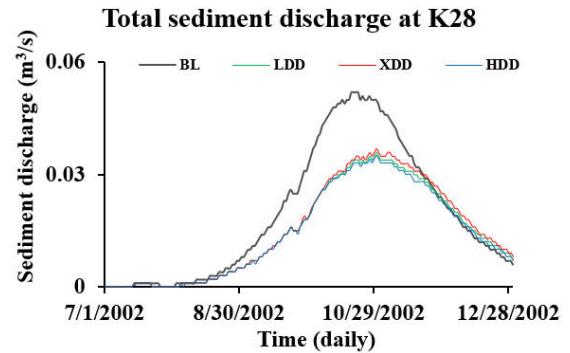

(c)

Figure 9. Total sediment discharge delivery to DTM via Cambodia border based on scenarios of hydropower dam development: (a) Total sediment discharge delivery to DTM via Binhthanh; (b) Total sediment discharge delivery to DTM via K79; (c) Total sediment discharge delivery to DTM via K28.

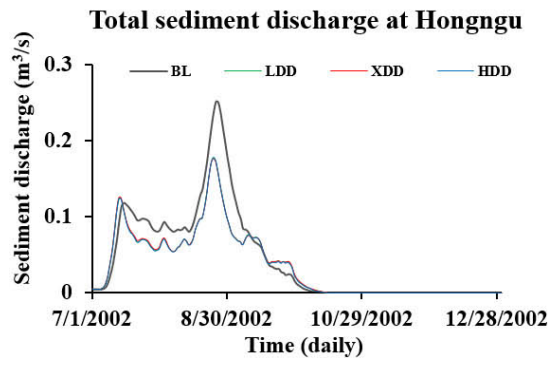

(a)

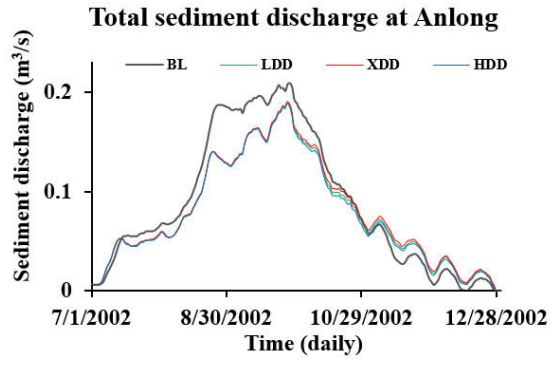

(b)

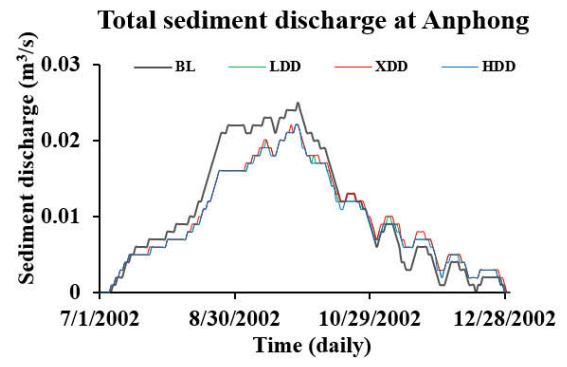

(c)

Figure 10. Total sediment discharge delivery to DTM via Tien River based on scenarios of hydropower dam development: (a) Total sediment discharge delivery to DTM via Hongngu; (b) Total sediment discharge delivery to DTM via Anlong; (c) Total sediment discharge delivery to DTM via Anphong.

Table 5. Cumulative sediment distribution in the DTM floodplains based on upstream dam development scenarios.

\begin{tabular}{ccccc}
\hline Zone & BL & LDD & XDD & HDD \\
\hline Tanchau & 62.78 & 57.72 & 58.56 & 57.03 \\
\% DTM/Tanchau & $3.41 \%$ & $3.05 \%$ & $3.06 \%$ & $3.04 \%$ \\
DTM & 2.14 & 1.76 & 1.79 & 1.73 \\
-Along Tien River & 1.23 & 1.07 & 1.09 & 1.06 \\
\% of DTM & $57.66 \%$ & $61.00 \%$ & $60.50 \%$ & $61.45 \%$ \\
-Along border & 0.91 & 0.69 & 0.71 & 0.67 \\
\% of DTM & $42.34 \%$ & $39.00 \%$ & $39.50 \%$ & $38.55 \%$ \\
\hline
\end{tabular}

tion associated with the former being slightly smaller than the others.

\section{Sediment distribution in DTM floodplains}

Table 5 shows the changes in cumulative sediment at Tanchau station and DTM floodplains where they are affected by low/high dam development conditions at the upstream of the LMD in comparison to the baseline scenario.

The total sediment transport at Tanchau station is decreased from 62.78 to 52.57 million $\mathrm{m}^{3}$ depending on anticipated scenarios. The development at the upstream will lead to the increase in water demand and completed hydropower dams in the upstream of the Mekong Basin, total sediment transport is strongly 
declined to 57.03 million $\mathrm{m}^{3}$ under HDD scenario. The total sediment transport is also decreased for the cases of LDD and XDD by 57.72 and 58.56 million $\mathrm{m}^{3}$, respectively. Accordingly, the total sediment transport rate, which is delivered to the DTM floodplains, is also reduced significantly from 2.14 million $\mathrm{m}^{3}$ (DTM/ Tanchau 3.41\%) under the baseline scenario to 1.73 million $\mathrm{m}^{3}$ (3.04\%), 1.76 million $\mathrm{m}^{3}(3.05 \%)$ and 1.79 million $\mathrm{m}^{3}$ (3.06\%) under HDD, LDD and XDD scenarios, respectively. Hence, high development with increasing water demand and water storage is a key factor to restrict volume of sediment delivered to the LMD floodplains of Vietnam.

Sediment delivery to the DTM floodplains is originated from 2 main sources, i.e. along the Tien River and overflow from the border of Cambodia floodplains. The amount of sediment delivered to the DTM via along the Tien River is about 1.23 million $\mathrm{m}^{3}$ (57.66\% of total sediment in the DTM) and via the border of Cambodia is about 0.91 million $\mathrm{m}^{3}$ (42.34\% of total sediment in the DTM). The upstream development has dramatically been affected the amount of sediment delivery as well as the proportion of main sediment sources to the DTM. The above impacts is presented through the fluctuation in total sediment transport at Tanchau station, main canals connecting to the Tien River and over the border of Cambodia floodplains. The achieved results pointed out that total sediment delivery to the DTM floodplains went down drastically when comparing development scenarios of hydropower dam with baseline (in Table 5). The proportion of transported sediment to the DTM floodplains via Tien River and the border of Cambodia showed a little change, i.e. the total transported sediment via along the Tien River to the DTM floodplains is raised from $57.66 \%$ to $61.45 \%$ in HDD, $61.00 \%$ in LDD and $60.50 \%$ in XDD. This may indicate that the development of hydropower dams and irrigation areas at the upstream of the LMD tend to decrease the total transported sediment not only from Tanchau to the LMD floodplains but also via the border of Cambodia to the DTM floodplains.

To clearly have a virtual vision about spatial sediment distribution in the DTM floodplains, the simulated cumulative sediment results in the 1-D hydrodynamics model are interpolated by using Kriging methods in ArcGIS to make maps of annual deposition rate based on the anticipated scenarios.

Figure 11 shows maps of the annual deposition rate for the simulated flood events based on baseline and development scenarios of hydropower dams. In the big flood of baseline 2002, the inundated area in DTM floodplains was much larger, while the sediment deposition rate was higher. A higher amount of sediment deposition delivered from the Tien River bring sediment into secondary canals and deposited in central DTM floodplains which far away from the Tien River about $40-60 \mathrm{~km}$, with a high deposition rate in a range of $3-40 \mathrm{~kg} \cdot \mathrm{m}^{-2}$ / wet season. Sediment delivery from the overland flood flow at the border of Cambodia obtained a high sediment concentration which also cumulated in the upstream of DTM floodplains and faraway from the Cambodia border about 30 - $50 \mathrm{~km}$, with the deposition rate of $6-40 \mathrm{~kg} \cdot \mathrm{m}^{-2} /$ wet season (see Figure 11(a)). However, some areas located near the Tien River and the Cambodia border, 


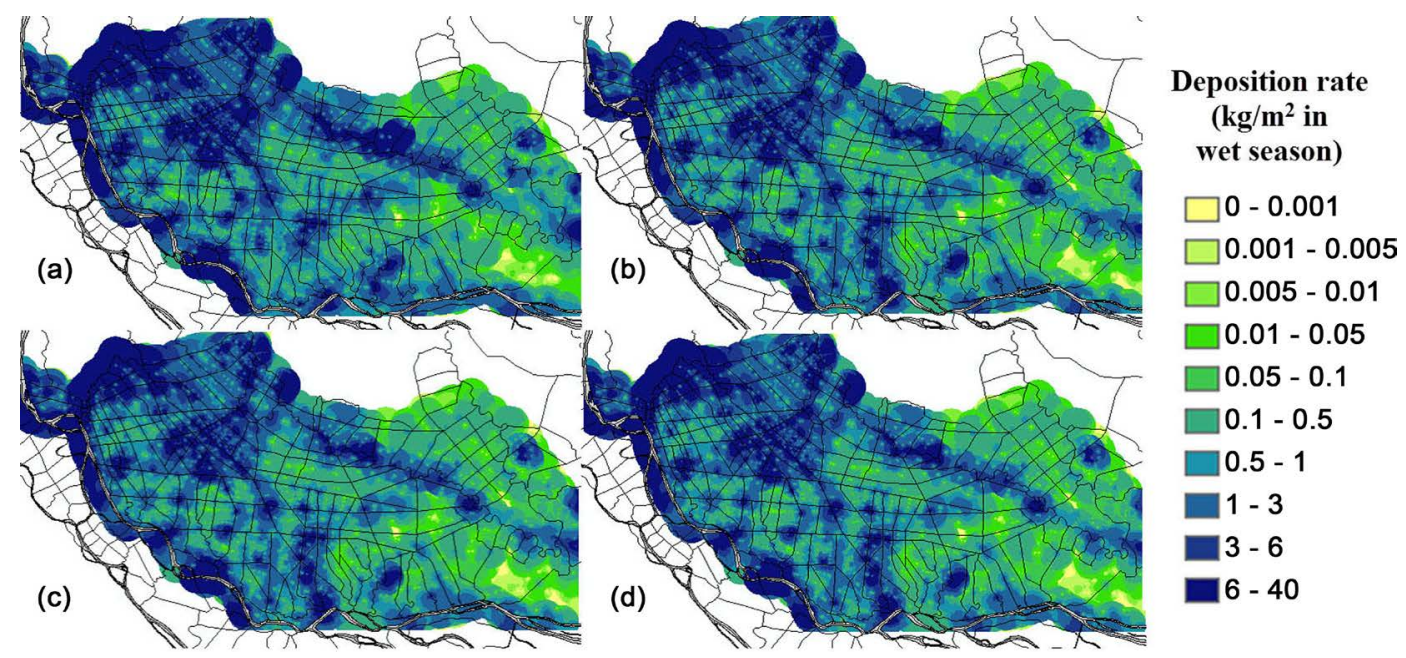

Figure 11. Maps of sediment distribution in the DTM floodplains: (a) Baseline; (b) HDD; (c) LDD; (d) XDD.

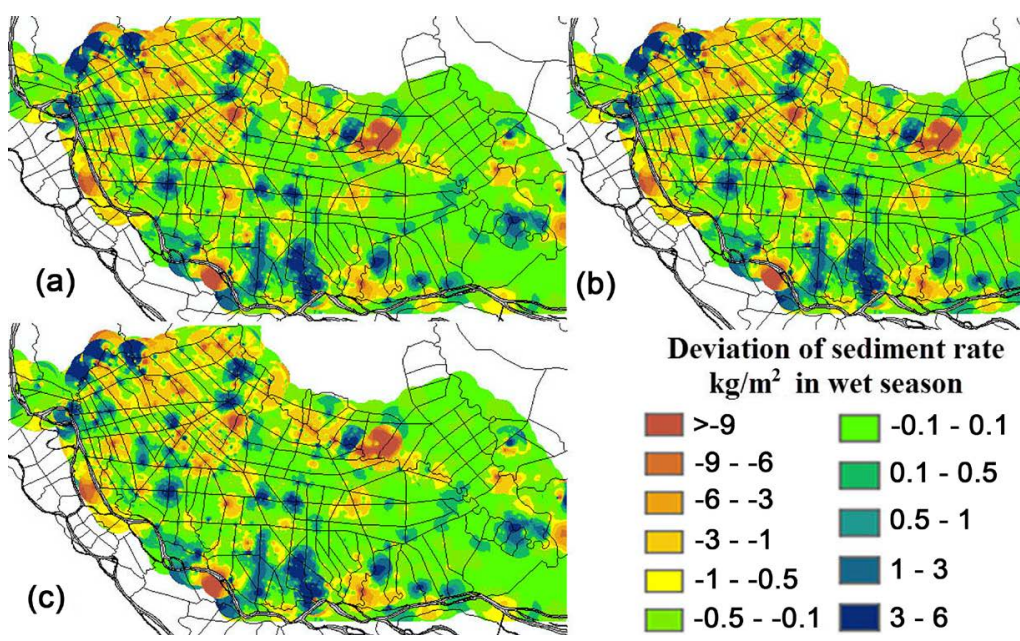

Figure 12. Deviation maps of sediment distribution in the DTM floodplains between development scenarios and baseline: (a) HDD-Baseline; (b) LDD-Baseline; (c) XDDBaseline.

sediment was not deposited as it may be because of the flood flow was enormous and the flow velocity was much higher than the settling velocity of sediment. As a result, most sediment contained in flood flow was placed faraway from DTM and accumulated in places where confluence of overflow from Cambodia and flood discharge from the Tien River.

The spatial variability of sediment deposition rate presents in Figures 11(b)-(d) showed the images of sediment distribution in DTM floodplains under the impacts of development scenarios from the upstream of LMD. Figure 12 spatially depicts the deviation of sediment deposition in DTM floodplains as compared to scenarios of developing construction in hydropower dams and irrigation area.

At the main gates along the Tien River, transported sediment to DTM (as Hongngu (P1), Anlong (P5), Phongmy (P8)) decreased (the same as other sedi- 
ment stations) (see Figure 2). In addition, the reduction in transported sediment occurred inside the DTM floodplains, while its amount is also dependent on the distance from the upstream of the main river to secondary canals (see Figure 12).

The achieved results indicated that, by upstream development of hydropower dams, the deposition rate was significantly declined in inundated areas located near the Cambodia border (about $3-6 \mathrm{~kg} \cdot \mathrm{m}^{-2} /$ wet season) and the central DTM floodplains (about $1-3 \mathrm{~kg} \cdot \mathrm{m}^{-2} /$ wet season). The effect of decrease in sediment deposition was higher in HDD and smaller in LDD and XDD scenarios. Figure 12(a) presents the changes in deposition rate as a result of HDD scenario in comparison to baseline, and Figure 12(b) and Figure 12(c) show the deviation in deposition rate of LDD and XDD scenarios in comparison to baseline.

The results basically represented effects of development in ascending water storage capability on sedimentation in the DTM floodplains. These abovementioned maps and tables depicted that sediment delivery from overflow at the border was much. Sediment delivery via the border of Cambodia to DTM floodplains is slightly inclined in high dam development (HDD) at the upstream of the Mekong River. In addition, it has almost no change in sediment transport at the Cambodia border under low and Xayaburi dam development (LDD and XDD) scenarios. Furthermore, the sediment delivery from the upstream along the Tien River was significantly affected by various scenarios of upstream dam development, but it has less influence to the overflow in Cambodia floodplains.

\section{Conclusions}

Sedimentation on floodplains in the Lower Mekong Delta is very important, but knowledge about sediment transport is limited. Based on the collection of historical sediment observation in DTM, this study improves the understanding of quantitative sediment deposition processes on floodplains under the impacts various dam developments at the upstream of the Mekong Basin.

According to the findings of this research, the simulated model evaluated the quantity of sediment deposition in spatial DTM floodplains from Kratie and overflow from the border of Cambodia. In general, higher deposition rate was occurred in closer distances to the two main sediment sources, i.e. along the Tien River and the border of Cambodia floodplains. The high sediment deposition was also found in central DTM floodplains where confluence of discharge from the Tien River and the overflow from the Cambodia border.

The deposition rate may decrease by the distance from the Mekong River and the secondary channels, while the source of the floodplain sediments also decrease by the distance to the main river. Deposition rate in the study area is quite high as compared to the other regions, and it is expected that the deposition rate will change when the hydrological conditions changed.

Besides that, the development in the upstream is one of the major factors leading a decrease in sediment discharge as well as sediment deposition in the downstream. To be specific, once the upstream of the Mekong Basin develops 
under the high/low development scenarios, deposition processes will significantly reduce in floodplains located close to the Cambodia border and the center of DTM.

Based on the present results, it may be helpful to contribute more details in understanding the sediment transport in LMD floodplains. In addition, it can be argued that natural or man-made actions that change floodplain inundation, e.g., the complete compartments or construction of dams along the upstream of the Mekong River may change the sediment delivery and also spatial sediment deposition in DTM floodplains.

\section{Acknowledgements}

This research was supported by the "Post-graduate Research programme on Adaptation to Climate Change in the Mekong River Basin-Phase 2" (PRoACC-2 project) funded by UNESCO-IHE Institute for Water Education, Delft, The Netherlands.

\section{References}

[1] Ngoc, T.A., Letrung, T., Hiramatsu, K. and Nguyen, T.Q. (2013) The Effect of Simulated Sea Level on the Sedimentation of the Tien River Estuaries, Lower Mekong River, Southern Vietnam. JARQ, 47, 405-415. https://doi.org/10.6090/jarq.47.405

[2] Mekong River Commission (MRC) (2010) Multi-Functionality of Paddy Fields over the Lower Mekong Basin. Technical Paper (26).

http://www.mrcmekong.org/assets/Publications/technical/tech-No26-multi-functio nality-of-paddy-field.pdf

[3] Letrung, T., Li, Q., Li, Y., Vukien, T. and Nguyenthai, Q. (2013) Morphology Evolution of Cuadai Estuary, Mekong River, Southern Vietnam. Journal of Hydrologic Engineering, 18, 1122-1123. https://doi.org/10.1061/(ASCE)HE.1943-5584.0000483

[4] Milliman, J.D. and Farnsworth, K.L. (2011) River Discharge to the Coastal Ocean: A Global Synthesis. Cambridge University Press, Cambridge, 143-144.

https://doi.org/10.1017/cbo9780511781247

[5] Wild, T.B. and Loucks, D.P. (2014) Managing Flow, Sediment, and Hydropower Regimes in the Sre Pok, Se San, and Se Kong Rivers of the Mekong Basin. Water Resources Research, 50, 5141-5157. https://doi.org/10.1002/2014WR015457

[6] Cenci, R.M. and Martin, J.M. (2004) Concentration and Fate of Trace Metals in Mekong River Delta. Science of the Total Environment, 332, 167-182. https://doi.org/10.1016/j.scitotenv.2004.01.018

[7] Hung, N.N., Delgado, J.M., Guentner, A., Merz, B., Bárdossy, A. and Apel, H. (2014) Sediment in the Floodplains of the Mekong Delta, Vietnam Part I: Suspended Sediment Dynamics. Hydrological Processes, 28, 3132-3144. https://doi.org/10.1002/hyp.9856

[8] Hung, N.N., Delgado, J.M., Guentner, A., Merz, B., Bárdossy, A. and Apel, H. (2014) Sediment in the Floodplains of the Mekong Delta, Vietnam Part II: Deposition and Erosion. Hydrological Processes, 28, 3145-3160. https://doi.org/10.1002/hyp.9856

[9] Wolanski, E., Nhan, N.H. and Spagnol, S. (1998) Sediment Dynamics during Low Flow Condition in the Mekong River Estuary, Vietnam. Journal of Coastal Research, 14, 472-482. 
[10] Wolanski, E., Huan, N.H., Dao, L.T., Nha, N.H. and Thuy, N.N. (1996) Fine Sediment Dynamics in the Mekong River Estuary, Vietnam, Estuarine. Coastal and Shelf Science, 43, 565-582. https://doi.org/10.1006/ecss.1996.0088

[11] Tamura, T., Horaguchi, K., Saito, Y., Nguyen, V.L., Tateishi, M., Ta, T.K.O., Nanayama, F. and Watanabe, K. (2010) Monsoon Influenced Variations in Morphology and Sediment of a Mesotidal Beach on the Mekong River Delta Coast. Geomorphology, 116, 11-23. https://doi.org/10.1016/j.geomorph.2009.10.003

[12] Mikhailov, V.N. and Arakelyants, A.D. (2010) Specific Features of Hydrological and Morphological Processes in the Mouth Area of the Mekong River. Water Resources, 37, 253-267. https://doi.org/10.1134/S0097807810030012

[13] Hung, N.N., Delgado, J.M., Tri, V.K., Hung, L.M., Merz, B., Bárdossy, A. and Apel, H. (2012) Floodplain Hydrology of the Mekong Delta, Vietnam. Hydrological Processes, 26, 674-686. https://doi.org/10.1002/hyp.8183

[14] Manh, N.V., Merz, B. and Apel, H. (2013) Sedimentation Monitoring Including Uncertainty Analysis in Complex Floodplains: A Case Study in the Mekong Delta, Hydrology and Earth System Sciences, 17, 3039-3057.

https://doi.org/10.5194/hess-17-3039-2013

[15] Manh, N.V., Dung, N.V., Hung, N.N., Merz, B. and Apel, H. (2014) Large-Scale Suspended Sediment Transport and Sediment Deposition in the Mekong Delta, Hydrology and Earth System Sciences, 18, 3033-3053. https://doi.org/10.5194/hess-18-3033-2014

[16] Lu, X.X. and Siew, R.Y. (2006) Water Discharge and Sediment Flux Changes over the Past Decades in the Lower Mekong River: Possible Impacts of the Chinese Dams. Hydrology and Earth System Sciences, 10, 181-195. https://doi.org/10.5194/hess-18-3033-2014

[17] Liu, X. and He, D. (2012) A New Assessment Method for Comprehensive Impact of Hydropower Development on Runoff and Sediment Changes. Journal of Geographical Sciences, 22, 1034-1044. https://doi.org/10.5194/hess-18-3033-2014

[18] Liu, C., He, Y., Walling, E. and Wang, J. (2013) Changes in the Sediment Load of the Lancang-Mekong River over the Period 1965-2003. Science China Technological Sciences, 56, 843-852. https://doi.org/10.1007/s11431-013-5162-0

[19] Mekong River Commission (MRC/DMS) (2010) Origin, Fate and Impacts of the Mekong Sediments. Mekong River Commission, 53.

http://www.mpowernetwork.org/Knowledge_Bank/Key_Reports/PDF/Research_Re ports/DMS_Sediment_Report.pdf

[20] Steiger, J., Gurnell, A.M. and Goodson, J.M. (2003) Quantifying and Characterizing Contemporary Riparian Sedimentation. River Research and Applications, 19, 335352. https://doi.org/10.1002/rra.708

[21] Steiger, J., Gurnell, A.M., Ergenzinger, P., Snelder, D. and Universita, F. (2001) Sedimentation in the Riparian Zone of an Incising River. Earth Surface Processes and Landforms, 108, 91-108. https://doi.org/10.1002/1096-9837(200101)26:1<91::AID-ESP164>3.0.CO;2-U

[22] Middelkoop, H. (2005) Floodplain Sedimentation-Methods, Patterns, and Processes: A Review with Examples from the Lower Rhine, The Netherlands. Encyclopedia of Hydrological Sciences, 1241-1282. https://doi.org/10.1002/0470848944.hsa085

[23] Baborowski, M., Büttner, O., Morgenstern, P., Krüger, F., Lobe, I., Rupp, H. and Tümpling, W.V. (2007) Spatial and Temporal Variability of sediment Deposition on Artificial-Lawn Traps in a Floodplain of the River Elbe. Environmental Pollution, 148, 770-778. https://doi.org/10.1016/j.envpol.2007.01.032 
[24] Habersack, H., Haspel, D. and Kondolf, M. (2014) Large Rivers in the Anthropocene: Insights and Tools for Understanding Climatic, Land Use, and Reservoir Influence. Water Resources Research, 50, 3641-3646.

https://doi.org/10.1002/2013WR014731

[25] DHI Water and Environment (DHI) (2009) MIKE 11 User Manual. DHI, Demark.

[26] DHI Water and Environment (DHI) (2009) MIKE 11 Reference. DHI, Demark.

[27] Havnø, K., Madsen, M.N. and Dørge, J. (1995) MIKE-11 a Generalized River Modelling Package. In: Singh, V.P., Ed., Computer Models of Watershed Hydrology, Water Resources Publications, Colorado, 733-782.

[28] Nielsen, S.A. and Hansen, E. (1973) Numerical Simulation of the Rainfall Runoff Process on a Daily Basis. Nordic Hydrology, 4, 171-190.

[29] Ngoc, T.A., Chinh, L.V., Hiramatsu, K. and Harada, M. (2011) Parameter Identification for Two Conceptual Hydrological Models of Upper Dau Tieng River Watershed in Vietnam. Journal of the Faculty of Agriculture, 56, 335-341.

[30] Ngoc, T.A., Hiramatsu, K. and Harada, M. (2013) Optimizing Parameters for Two Conceptual Hydrological Models Using A Genetic Algorithm. JARQ, 47, 85-96. https://doi.org/10.6090/jarq.47.85

[31] Van Rijn, L.C. (1984) Sediment Transport, Part I: Bed Load Transport. The Journal of Hydraulic Engineering, 110, 1431-1456. https://doi.org/10.1061/(ASCE)0733-9429(1984)110:10(1431)

\section{Submit or recommend next manuscript to SCIRP and we will provide best} service for you:

Accepting pre-submission inquiries through Email, Facebook, LinkedIn, Twitter, etc. A wide selection of journals (inclusive of 9 subjects, more than 200 journals)

Providing 24-hour high-quality service

User-friendly online submission system

Fair and swift peer-review system

Efficient typesetting and proofreading procedure

Display of the result of downloads and visits, as well as the number of cited articles

Maximum dissemination of your research work

Submit your manuscript at: http://papersubmission.scirp.org/

Or contact jwarp@scirp.org 